\title{
Children and Social Policy
}


Also by Paul Daniel

Social Work and Local Politics (with J. Wheeler) 


\section{Children and Social Policy}

Paul Daniel and John Ivatts 


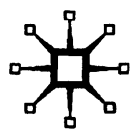

- Paul Daniel and John Ivatts 1998

All rights reserved. No reproduction, copy or transmission of this publication may be made without written permission.

No paragraph of this publication may be reproduced, copied or transmitted save with written permission or in accordance with the provisions of the Copyright, Designs and Patents Act 1988, or under the terms of any licence permitting limited copying issued by the Copyright Licensing Agency, 90 Tottenham Court Road, London W1T 4LP.

Any person who does any unauthorised act in relation to this publication may be liable to criminal prosecution and civil claims for damages.

The authors have asserted their rights to be identified as the authors of this work in accordance with the Copyright, Designs and Patents Act 1988.

Published by

PALGRAVE

Houndmills, Basingstoke, Hampshire RG21 6XS and 175 Fifth Avenue, New York, N. Y. 10010

Companies and representatives throughout the world

PALGRAVE is the new global academic imprint of St. Martin's Press LLC Scholarly and Reference Division and Palgrave Publishers Ltd (formerly Macmillan Press Ltd).

ISBN 978-0-333-65208-4 ISBN 978-1-349-26277-9 (eBook)

DOI 10.1007/978-1-349-26277-9

This book is printed on paper suitable for recycling and made from fully managed and sustained forest sources.

A catalogue record for this book is available from the British Library.

$\begin{array}{rrrrrrr}10 & 9 & 8 & 7 & 6 & 5 & 4 \\ 07 & 06 & 05 & 04 & 03 & 02 & 01\end{array}$

Copy-edited and typeset by Povey-Edmondson Tavistock and Rochdale 
To our children and grandchildren Andrew, Eleanor, Mark, Nicole, Oliver, Rachel and Simone 


\section{Contents}

List of Tables and Figures xiii Acknowledgements xiv

Introduction $\quad 1$

1 Social Policy and Childhood: An Overview 4

Introduction 4

Children come first? 5

The family: a dominant theme in UK social policy 6

The state-family relationship $\quad 8$

Child as threat $\quad 11$

Child as victim $\quad 13$

Child as investment 13

The liberal dilemma 15

The United Nations Convention on the Rights of the Child 16

Conclusion $\quad 21$

2 Children in Britain Today 22

Introduction - population studies 22

Determinants of the size of the child population 23

Long-term fertility trends in the United Kingdom 27

The child population 29

The geographical distribution of the child population 31

The children of ethnic minority groups 32

Children growing up in lone-parent families 36

'Reconstituted' families 39

Other child minorities 40

The changing experience of childhood since 1945

Conclusion 46

3 Children and Poverty 50

Introduction 50

The end of the line for poverty? 51

Poverty as social exclusion $\quad 52$ 
Measuring the extent of child poverty 56

Child poverty since 1945

The causes of child poverty $\quad 59$

Family Allowance/Child Benefit $\quad 62$

A minimum wage $\quad 65$

Benefits for families out of work $\quad 67$

4 Child Health and Health Care Policy 75

Introduction $\quad 75$

$\begin{array}{ll}\text { Health care policy and children } & 76\end{array}$

The National Health Service 78

'Working for Patients' and the 1991 NHS reorganisation $\quad 80$

Child health care within the reorganised NHS 82

Inequalities in health among children $\quad 87$

Contemporary health risks to children 93

$\begin{array}{ll}\text { Conclusion } & 107\end{array}$

5 Housing Policy and Children 110

Introduction $\quad 110$

Housing policy and progress 1945-79 111

Post-war housing policy and children 113

Housing policy since $1979 \quad 120$

The consequences for children of post-1979 housing policies

Homelessness $\quad 132$

The effects of homelessness on children 138

Conclusion $\quad 143$

6 Early Childhood Education and Care 145

Introduction $\quad 145$

The low status of early childhood 146

The education/care division 148

Early years day care and adult interests $\quad 148$

'Investing' in young children 149

The pattern of provision: choice or lottery? 151

The mixed economy of provision 154

The quality of provision $\quad 159$

$\begin{array}{ll}\text { Nursery vouchers } & 162\end{array}$

Day care for school-age children 164

Towards child-friendly employment policies $\quad 165$

$\begin{array}{ll}\text { Conclusion } & 166\end{array}$ 
$\begin{array}{lll}7 & \text { Primary Education } & 167\end{array}$

Introduction $\quad 167$

The establishment of primary education $\quad 169$

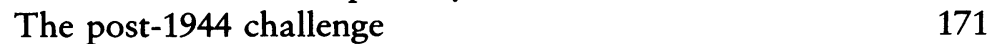

Progress and problems in primary education from the 1940s to the 1970s 172

Educational change 1979-96 176

The primary school curriculum 179

Standards and classroom methods in primary education 181

A wider choice for parents? $\quad 184$

Disadvantaged children 187

Resources for primary education $\quad 189$

Independent schools $\quad 192$

$\begin{array}{ll}\text { Conclusion } & 194\end{array}$

8 Child Welfare and Protection 196

Introduction 196

The 'liberal compromise' 197

An age of optimism, 1945-70 201

The 1970s: the permanency philosophy 203

The contemporary dominance of child protection 204

The Children Act $1989 \quad 205$

Children in care/accommodation 208

Black children and the care system 209

The growth of fostering 210

Residential care 211

The experience of children in care/accommodation 213

Adoption 215

Conclusion 217

9 The Century of the Child? 219

Introduction 219

Children of the 'welfare state', 1945-79 221

From a 'universalist' to an 'affordable' welfare state 222

Children in a changing welfare state 224

Towards greater prominence for children in social policy 228

Institutional change for the empowerment of children? $\quad 230$

Conclusion 234

Bibliography 236

Index 253 


\section{List of Tables and Figures}

\section{Tables}

2.1 Number of children, United Kingdom, by age and gender

2.2 Population, Great Britain, by ethnic group and age, spring 1995

6.1 Places in early years' education and care facilities in the United Kingdom, 1951-1992/93

\section{Figures}

2.1 United Kingdom live births, 1944-94 and estimated population, mid-1994

2.2 Total period fertility rate (TPFR) in the United Kingdom, 1944-94 


\section{Acknowledgements}

We are greatly indebted to the many Social Policy and Early Childhood Diploma students whose desire for understanding and acute concern for children's welfare have provided a rich source of ideas, and indeed the original inspiration for this book. To our colleagues in the Sociology and Social Policy Department at the Roehampton Institute we also owe a great deal. Their encouragement and fecund comments upon some of the original material contributed substantially to the development of the content of this text. Thus our particular thanks to Martin Albrow, John Baker, David Denney, Graham Fennell, Stephen Groarke, Robert Leaper and Lorraine Radford. To Jane Lambert, Peter Jackson, Arthur Ivatts, Simone Ivatts and Edith Le Riche we are also particularly grateful for their expert advice on specific subject matter. The completion of a book of this kind depends upon the works of innumerable writers and researchers. We gratefully acknowledge our debt to all those who have contributed to the store of public knowledge upon which we have been able to draw so copiously. The task of writing this text has also been greatly facilitated by the unfailing help and courteous efficiency of the staff of the Roehampton Institute libraries and of the Horsham branch of the West Sussex public library service; our appreciation in this connection to Pat Biggs, James Chislett, Julie Harrison and Maria Hisco, and to Andrea Peace and her colleagues at Southlands College Library. Finally, and above all, we owe an immeasurable debt of gratitude to Joanna Ball and Rose-Marie Ivatts who have not only shared the stresses of authorship with great patience, but have provided invaluable support and encouragement throughout.

Paul Daniel JOHN IvatTS

The authors and publishers gratefully acknowledge the permission given by the Controller of HMSO and The Office for National Statistics to reproduce the material used in the figures and tables. 